\title{
Crude glycerin in supplement to primiparous lactating cows grazing on tropical pasture: nutritional and productive characteristics
}

\author{
Hermógenes Almeida de Santana Júnior ${ }^{1}$, Mauro Pereira Figueiredo ${ }^{2}$, Elizangela Oliveira \\ Cardoso $^{3}$, Fabrício Bacelar Lima Mendes ${ }^{3}$, George Abreu Filho ${ }^{3}$, Alyson Andrade Pinheiro ${ }^{4}$, \\ Pablo Teixeira Viana ${ }^{3}$, João Paulo Santos Roseira ${ }^{2}$
}

\footnotetext{
${ }^{1}$ Universidade Estadual do Piauí.

2 Universidade Estadual do Sudoeste da Bahia, Vitória da Conquista Campus, Vitória da Conquista/BA

${ }^{3}$ Universidade Estadual do Sudoeste da Bahia, Itapetinga Campus, Itapetinga/BA.

${ }^{4}$ Universidade Federal da Bahia, Salvador/BA.
}

\begin{abstract}
The objective of this study was to evaluate the nutritional and productive characteristics of primiparous lactating cows grazing on tropical pasture, using different levels of crude glycerin in the supplement. The experiment was conducted at Rancho Santana farm, located in Jequié city, Bahia, Brazil, in the period from December 21, 2010 to March 16, 2011. Ten $3 / 4$ Holstein $\times 1 / 4$ Dairy Gyr lactating primiparous cows, with $109 \pm 24$ days of lactation and a mean age of $30 \pm 6$ months and mean body weight of $426.2 \pm 68.29 \mathrm{~kg}$ were distributed into five treatments, using two simultaneous $5 \times 5$ latin squares. Treatments consisted of inclusion levels $(0,94,191,289,389 \mathrm{~g} / \mathrm{kg}$ dry matter basis) of crude glycerin in the supplement. Intake, digestibility, milk production and composition were measured. Results were statistically analyzed by analysis of variance and regression at 0.05 probability. For all consumption variables no significant differences were found between the levels of crude glycerin. Except for the digestibility of ether extract, all digestibility values were similar between treatments. The fat content and yield showed quadratic effect between treatments. No significant differences were observed for protein, lactose, total solids, nonfat dry extract, fat:protein ratio, milk urea nitrogen and somatic cell count between treatments. For primiparous lactating cows grazing on tropical pasture, up to $389 \mathrm{~g}$ of crude glycerin $/ \mathrm{kg}$ of dietary supplement can be included without nutritional and productive interference.
\end{abstract}

Key Words: biodiesel, co-product, glycerol, intake, supplementation

\section{Introduction}

Brazil is the sixth largest milk producer worldwide and has great potential to meet the growing domestic consumption and increase participation as an exporter of dairy products. However, in order to consolidate this scenario, it is necessary to increase the production of high-quality milk and keep costs consistent with business profitability.

Glycerol, or propane-1, 2, 3-triol, is an organic compound belonging to the alcohol function; it is liquid at room temperature $\left(25^{\circ} \mathrm{C}\right)$, hygroscopic, odorless, viscous and sweet in taste. With the introduction of vegetable oil in the biofuel production chain in Brazil, the supply of glycerol in the market is expected to increase, although the demand is not proportional to the supply, causing an environmental barrier.

The inclusion of glycerol in feed to replace corn is a possible alternative for formulating diets for lactating cows, in addition to the results of decreased production costs, considering the market prices. However, additional information on the economic evaluation of its inclusion in diets is needed to determine the effects of glycerol on relevant characteristics such as consumption, milk production and digestibility, especially in diets where intake and digestibility of fiber may limit the performance (Donkin et al., 2009).

The objective of this study was to evaluate the nutritional and productive characteristics of primiparous lactating cows grazing on tropical pastures with different levels of crude glycerin in the supplement.

\section{Material and Methods}

The experiment was carried out at Rancho Santana farm in Jequie, Bahia State, Brazil, located at $13^{\circ} 52^{\prime} 14^{\prime \prime}$ South, $40^{\circ} 09^{\prime} 47^{\prime \prime}$ West longitude, with an average altitude of $260 \mathrm{~m}$. Fieldwork was conducted between December 21, 2010 and March 16, 2011, deployed in an area of $7600 \mathrm{~m}^{2}$, divided into 14 paddocks of approximately $543 \mathrm{~m}^{2}$ each, formed with Brachiaria brizantha MG-5, irrigated with fixed spray sprinklers and fertilized during the experiment 
with $240 \mathrm{~kg} \mathrm{~N} / \mathrm{ha}$, in the form of urea, distributed throughout the experimental period. Temperature (thermometer with maximum and minimum range of -40 to $+50{ }^{\circ} \mathrm{C}$, Walmur ${ }^{\circledR}$ ), precipitation and irrigation data were collected during the experimental period (Table 1). The rotational grazing paddocks used had one day of occupation and 13 days of rest.

Ten $3 / 4$ Holstein $\times 1 / 4$ Dairy Gyr lactating primiparous cows, with $109 \pm 24$ days of lactation, average initial age of $30 \pm 6$ months and average initial body weight of $426.2 \pm 68.29 \mathrm{~kg}$ were distributed in five treatments using two simultaneous $5 \times 5$ latin squares.

Treatments consisted of different levels of crude glycerin in the supplement: no glycerin inclusion in the supplement (control); 94; 191; 289; and $389 \mathrm{~g}$ glycerin $/ \mathrm{kg}$ supplement (Table 2).

The morning milking was done at $05 \mathrm{~h} 00$ and the second milking at 16 h00. Portable milking bucket equipment was used to milk cows in a single return lane milking parlor. The concentrate supplement was provided individually immediately after milking, in a polypropylene trough, with availability of 100 linear centimeters per animal.

Table 1 - Average temperature, total precipitation and total irrigation during each period and on the average of the periods

\begin{tabular}{lcccccc}
\hline \multirow{2}{*}{ Item } & \multicolumn{7}{c}{ Period } & Average \\
\cline { 2 - 6 } & 1st & 2nd & 3rd & 4th & 5th & \\
\hline Minimum T, shade & 23.7 & 22.0 & 22.9 & 24.1 & 22.9 & 23.1 \\
Maximum T, shade & 35.4 & 34.7 & 37.7 & 41.7 & 37.7 & 37.4 \\
Minimum T, sun & 21.8 & 20.0 & 20.3 & 21.7 & 20.5 & 20.9 \\
Maximum T, sun & 37.8 & 37.1 & 40.1 & 43.1 & 42.2 & 40.1 \\
Precipitation (mm) & 33 & 13 & 52 & 0 & 157 & 51 \\
Irrigation (mm) & 170 & 165 & 152 & 180 & 20 & 137 \\
\hline
\end{tabular}

1st period: $01 / 01 / 2011$ to $01 / 15 / 2011$; 2 nd period: $01 / 16 / 2011$ to $01 / 30 / 2011$; 3 rd period: $01 / 31 / 2011$ to $02 / 14 / 2011$; 4 th period: $02 / 15 / 2011$ to $03 / 01 / 2011$; 5 th period: $03 / 02 / 2011$ to $03 / 16 / 2011$.

$\mathrm{T}$ - temperature.
The animals underwent a 10-day adaptation period to the coproduct prior to initiation of the experimental period, based on the recommendation of Donkin et al. (2009) offering an intermediate diet (191 g glycerin $/ \mathrm{kg}$ supplement). The experiment lasted 75 days, divided into five periods of 15 days each with 10 days for adaptation to experimental diets and five days for data collection.

Pasture was monitored daily, using the methods of McMeniman (1997), Wilm et al. (1994), Gardner (1986) and Campbell (1966), for the collection and evaluation of total residual biomass (TRB), forage biomass availability and accumulation rate (AR), respectively (Table 3 ).

Stocking rate (SR) was calculated considering the animal unit (AU, $450 \mathrm{~kg} \mathrm{BW})$. The forage allowance (FA) was calculated using the following formula: $F A=\{(T R B$ $\times$ area $+\mathrm{AR} \times$ area) $/ \mathrm{BWtotal}\} \times 100$, where: $\mathrm{FA}=$ forage allowance, $\mathrm{kg} \mathrm{DM} / 100 \mathrm{~kg} \mathrm{BW} /$ day; TRB = total residual biomass in $\mathrm{kg} \mathrm{DM} / \mathrm{ha} /$ day; $\mathrm{AR}=$ accumulation rate in $\mathrm{kg}$ $\mathrm{DM} / \mathrm{ha} /$ day; and BWtotal = total body weight of the animal in $\mathrm{kg} / \mathrm{ha}$.

The pasture potentially digestible DM (pdDM) was calculated as described by Paulino et al. (2006), by the equation: $\mathrm{pdDM}=0.98 \times(100-\% \mathrm{NDF})+(\% \mathrm{NDF}-$ $\% \mathrm{NDFi}$ ). The height of compressed forage was measured through a graduated scale, with the aid of a transparent plastic sheet, at all points of forage collection. During the period of collection (last five days of each period) samples were collected from simulated grazing, obtained through observation of animals, identifying the type of material consumed and collecting a sample similar to the feed ingested (Johnson, 1978).

To estimate the fecal output, LIPE $^{\circledR}$ (isolated, purified and enriched lignin Eucalyptus grandis, UFMG, Minas Gerais) was used as an external marker. One capsule of which was administered after the morning feeding of

Table 2 - Concentrate proportion of ingredients and bromatological composition (dry matter basis)

\begin{tabular}{|c|c|c|c|c|c|}
\hline \multirow{2}{*}{ Item } & \multicolumn{5}{|c|}{ Crude glycerine level (g/kg) } \\
\hline & 0 & 94 & 191 & 289 & 389 \\
\hline Whole corn grain ground $(\mathrm{g} / \mathrm{kg})$ & 772 & 653 & 531 & 407 & 281 \\
\hline Soybean meal $(\mathrm{g} / \mathrm{kg})$ & 201 & 224 & 249 & 274 & 300 \\
\hline Limestone $(\mathrm{g} / \mathrm{kg})$ & 9 & 9 & 9 & 9 & 8 \\
\hline Dicalcium phosphate $(\mathrm{g} / \mathrm{kg})$ & --- & --- & --- & --- & 1 \\
\hline Mineral salt $(\mathrm{g} / \mathrm{kg})^{1}$ & 20 & 20 & 20 & 20 & 20 \\
\hline Total digestible nutrients $(\mathrm{g} / \mathrm{kg} \mathrm{DM})$ & 70.4 & 72.2 & 70.6 & 69.5 & 71.7 \\
\hline Non-fiber carbohydrates (g/kg DM) & 60.2 & 60.6 & 60.3 & 59.1 & 58.9 \\
\hline NDFap (g/kg DM) & 9.8 & 9.5 & 9.2 & 8.7 & 8.8 \\
\hline
\end{tabular}

DM - dry matter; NDFap - neutral detergent fiber corrected for ash and protein.

${ }^{1}$ Composition: calcium - 200 g; phosphorus - 100 g; sodium - 68 g; magnesium - 15 g; sulfur - 12 g; cobalt - 200 mg; copper - 1650 mg; iodine - 195 mg; manganese - 1960 mg; nickel - $40 \mathrm{mg}$; selenium - $32 \mathrm{mg}$; zinc - $6285 \mathrm{mg}$; iron - $560 \mathrm{mg}$; fluorine (maximum) - $1000 \mathrm{mg}$. 
the concentrate for seven days, including three days for adjusting and regulating the flow of excretion of the marker and four days for collection of feces. To determine the internal marker, indigestible neutral detergent fiber (NDFi), samples of forage, feces and concentrates were incubated in the rumen of four fistulated animals for 240 hours (Casali et al., 2008), using bags of TNT 100 (non-woven textile), considering the ratio of $20 \mathrm{mg}$ of sample/ $\mathrm{cm}^{2}$ and the residue after incubation regarded as the indigestible portion.

Dry matter intake (Table 4) was obtained by the following equation: $\mathrm{DMI}=\{[(\mathrm{FO} \times \mathrm{CIF})-\mathrm{IS}] / \mathrm{CIFR}\}$ + DMIS, where in DMI is the dry matter intake ( $\mathrm{kg} /$ day); FO is fecal output (kg/day); CIF is the concentration of the marker present in the stool $(\mathrm{kg} / \mathrm{kg})$, IS is the marker present in the supplement $(\mathrm{kg} /$ day); CIFR is the concentration of the marker present in the harvested forage as simulated grazing $(\mathrm{kg} / \mathrm{kg})$; and DMIS is the dry matter intake of the supplement $(\mathrm{kg} /$ day).

Laboratory tests were performed at Laboratório de Nutrição Animal of Universidade Estadual do Sudoeste da Bahia - UESB, Campus Vitória da Conquista, Bahia, Brazil. Samples of concentrate supplement, simulated grazing (Table 4) and feces were dried in a pre-forced ventilation oven at $55{ }^{\circ} \mathrm{C}$ for 72 hours. Dry matter (DM), crude protein $(\mathrm{CP})$, mineral matter $(\mathrm{MM})$ and ether extract (EE) were analyzed according to the AOAC (2000). Neutral detergent fiber corrected for ash and protein (NDFap) and acid detergent fiber (ADF) were analyzed by the sequential method, according to Detmann \& Valadares Filho (2010). The non-fiber carbohydrates (NFC) were calculated as the difference between total carbohydrate and NDFap.
Milk production was assessed from days 11 through 15 of each experimental period. The calculation of the milk production corrected for $35 \mathrm{~g} / \mathrm{kg}$ fat (MPc) was done using the following formula (Tyrrell \& Reid, 1965): MPc = $12.82 \times \mathrm{FP}+7.13 \times \mathrm{PTP}+0.323 \times \mathrm{MP}$, where: $\mathrm{FP}=$ fat production, $\mathrm{kg}$ /day; $\mathrm{PTP}=$ protein production, $\mathrm{kg}$ /day; and $\mathrm{MP}=$ milk production, $\mathrm{kg} /$ day .

The body condition score was evaluated by the same observer using a five-point scale $(1=$ thin, 5 = fat $)$, in increments of 0.25 units for every intermediate one (Edmonson et al. 1989). The animals were weighed at the beginning and end of each collection period for evaluation of the variation of body weight.

To determine their composition, milk samples were individually collected in two consecutive milking sessions, on the 13th and 14th days of each period. Aliquots were composed of $20 \mathrm{~mL} / \mathrm{L}$ produced (Eifert et al., 2006) from the morning and afternoon milking sessions, and the proportionality of production of each animal training was considered for the composite sample. Fat content, protein, lactose and total solids were analyzed by infrared Bentley 2000 analyzer (Bentley Instruments ${ }^{\circledR}$ ), blood urea nitrogen by Chemspec 150 (Bentley Instruments ${ }^{\circledR}$ ) and somatic cell count (SCC) by the cytometry flowmetric method of Somacount 300 (Bentley Instruments ${ }^{\circledR}$ ), all in Clínica do Leite of ESALQ/USP.

In all variables, every animal represented one experimental unit. The results were statistically analyzed by analysis of variance and regression at 0.05 probability, using program SAEG (Sistema para Análises Estatísticas e Genéticas, version 9.1).

Table 3 - Average and standard deviation (SD) of forage characteristics during the experimental period

\begin{tabular}{lcccccccccccc}
\hline & $\mathrm{TDMA}^{1}$ & $\mathrm{GDMA}^{1}$ & $\mathrm{pdDM}^{2}$ & $\mathrm{TRB}^{3}$ & $\mathrm{SR}^{4}$ & $\mathrm{AR}^{3}$ & $\mathrm{FA}^{5}$ & $\mathrm{FH}^{6}$ & $\mathrm{~L}^{2}$ & $\mathrm{~S}^{2}$ & $\mathrm{DeM}^{2}$ \\
\hline Average & 5367 & 4187 & 720 & 1945 & 12.5 & 263 & 39 & 52 & 38 & 52 & 10 \\
SD & \pm 1243 & \pm 745 & \pm 5 & \pm 206 & \pm 0.2 & \pm 47 & \pm 8 & \pm 2 & \pm 5 & \pm 6 & \pm 2 \\
\hline
\end{tabular}

TDMA - total dry matter availability; GDMA - green dry matter availability; pdDM - potentially digestible dry matter; TRB - total residual biomass; SR - stocking rate; AR accumulation rate; FA - forage allowance; FH - forage height; L - leaf; S - stalk; DeM - dead matter; DM - dry matter; BW - body weight.

${ }^{1}$ Expressed in $\mathrm{kg} / \mathrm{ha}$.

${ }^{2}$ Expressed in $\mathrm{g} / \mathrm{kg}$.

${ }^{3}$ Expressed in $\mathrm{kg} \mathrm{DM} / \mathrm{ha} /$ day.

${ }^{4}$ Expressed in AU/ha.

${ }^{5}$ Expressed in $\mathrm{kg} \mathrm{DM} / 100 \mathrm{~kg} \mathrm{BW} /$ day.

${ }^{6}$ Expressed in $\mathrm{cm}$.

Table 4 - Bromatological composition of the forage samples collected by simulated grazing during the respective experimental periods

\begin{tabular}{|c|c|c|c|c|c|c|}
\hline \multirow{2}{*}{ Item } & \multicolumn{5}{|c|}{ Period } & \multirow{2}{*}{ Average } \\
\hline & $1 \mathrm{st}$ & 2nd & $3 \mathrm{rd}$ & 4 th & 5 th & \\
\hline Dry matter $(\mathrm{g} / \mathrm{kg})$ & 298 & 320 & 307 & 251 & 323 & 300 \\
\hline Organic matter $(g / k g ~ D M)$ & 917 & 896 & 906 & 907 & 909 & 907 \\
\hline Neutral detergent fiber $(\mathrm{g} / \mathrm{kg} \mathrm{DM})^{1}$ & 614 & 644 & 616 & 624 & 618 & 623 \\
\hline Acid detergent fiber (g/kg DM) & 374 & 378 & 356 & 366 & 376 & 370 \\
\hline Crude protein $(\mathrm{g} / \mathrm{kg} \mathrm{DM})$ & 133 & 143 & 137 & 132 & 145 & 133 \\
\hline Non-fiber carbohydrates (g/kg DM) & 140 & 70 & 129 & 109 & 127 & 115 \\
\hline
\end{tabular}

${ }^{1}$ Corrected for ash and protein 


\section{Results and Discussion}

For all consumption variables there were no significant differences $(\mathrm{P}>0.05)$ between the levels of crude glycerin (Table 5). The lack of effects of adding glycerol to the total dry matter intake (TDMI) is consistent with other findings of research conducted in feedlot (DeFrain et al., 2004; Chung et al., 2007; Donkin et al., 2007; Donkin et al., 2009; Wang et al., 2009). However, our findings were in contrast with the studies of Fisher et al. (1971), who reported that glycerol stimulated consumption when the animals were fed $472 \mathrm{~g} /$ day in the concentrate, and Ogborn (2006), who stated that this trialcool has a depressive effect on consumption. Other studies (Fisher et al., 1971; Ogborn, 2006) reported that this intake variation is a function of metabolizable energy supply, while at high energy supply, according to the high level of glycerol, there is a reduction in consumption, while providing moderate glycerol favors the efficiency of utilization of nutrients, increasing ingestion.

Wang et al. (2009) state that these varying effects of glycerol on the TDMI may be due to the quality of coproduct used, the level of addition of glycerol or the proportion of concentrate and roughage in the diet. On the market there are basically two forms in which glycerin is presented: purified with a content of $95 \%$ glycerol and crude with various levels of glycerol, but always lower than the content of the purified glycerin. With the similar TDMI between the levels of crude glycerin (Table 5), we verify that it is composed of the sum of the similar consumption of forage and supplement in the different rations. Therefore, there was no relationship between the level of dietary crude glycerin and forage DM intake.

Given that the crude glycerin is liquid at room temperature, with the inclusion of $390 \mathrm{~g}$ per $\mathrm{kg}$, which made the supplement pastier, even then, this physical change in its consistency did not promote rejection of the supplement.
Mertens (1987) highlights that food assessment begins by checking for intake by these animals, assessing its acceptability and intake rate (ability to ingest the neutral detergent fiber). In this context, the crude glycerin does not influence the consumption of the fibrous carbohydrate fraction, thus permitting its use in feed for lactating cows consuming tropical pastures.

The nutrient intake did not differ $(\mathrm{P}>0.05)$ between the levels of crude glycerin in the supplement, since they were similar in chemical bromatological composition, besides the fact that diets were also isoenergetic and isonitrogenous, having equal TDMI, which certainly influenced these results. Donkin et al. (2009) reported that the use of neutral detergent fiber decreased with the increase of glycerol in the diet, suggesting the need for further studies for the understanding of the effects on the ingestion and digestion of NDF.

With the exception of ether extract digestibility (EED), all digestibility values were similar between the levels of crude glycerin $(\mathrm{P}>0.05)$ (Table 6). Observing mean results for the EED found in each treatment, those with crude glycerin inclusion were close to each other and different from control. This lower result found for this variable can be explained by the lower digestibility for the diet without the coproduct. Khalili et al. (1997) stated that the supply of glycerol along with plants that have a high content of fatty acids (lipids) increases the digestibility of lipids, leading to the argument that the interaction of glycerol and fatty acids results in an increase in the production of MPc (Khalili et al., 1997), being a consequence of increased digestibility of lipids.

Donkin et al. (2009), working with glycerol levels in the diet $(0,50,100$ and $150 \mathrm{~g} / \mathrm{kg})$ of Holstein cows, found increases in the digestibility of DM (DMD), organic matter (OMD) and crude protein (CPD). No differences were found in NDF digestibility (NDFD) between the

Table 5 - Daily intake of lactating primiparous cows grazing on tropical pasture with levels of crude glycerin inclusion in the supplement and their respective coefficients of variation $(\mathrm{CV}, \%)$

\begin{tabular}{|c|c|c|c|c|c|c|c|c|c|}
\hline \multirow{2}{*}{ Item } & \multicolumn{5}{|c|}{ Levels of crude glycerin (g/kg supplement) } & \multirow{2}{*}{$\mathrm{CV}$} & \multicolumn{3}{|c|}{$P$ value } \\
\hline & 0 & 94 & 191 & 289 & 389 & & Linear & Quadratic & Lack of fit \\
\hline Forage DM intake $(\mathrm{kg})$ & 9.59 & 8.63 & 8.52 & 8.74 & 9.55 & 13.7 & 0.2232 & 0.4829 & 0.4302 \\
\hline Forage DM intake(g/kg BW) & 22.3 & 20.3 & 19.5 & 20.4 & 22.5 & 24.6 & 0.2733 & 0.5393 & 0.3855 \\
\hline Total DM intake $(\mathrm{kg})$ & 14.24 & 13.28 & 13.17 & 13.40 & 14.20 & 9.1 & 0.5390 & 0.6942 & 0.5838 \\
\hline Total DM intake (g/kg BW) & 33.1 & 31.0 & 30.2 & 31.3 & 33.5 & 21.2 & 0.6745 & 0.8756 & 0.3901 \\
\hline Neutral detergent fiber intake $(\mathrm{kg})$ & 7.06 & 6.37 & 6.34 & 6.48 & 7.01 & 12.2 & 0.5238 & 0.7982 & 0.6081 \\
\hline Neutral detergent fiber intake $(\mathrm{g} / \mathrm{kg} \mathrm{BW})$ & 16.4 & 15.0 & 14.5 & 15.1 & 16.5 & 23.5 & 0.6345 & 0.7238 & 0.4872 \\
\hline Organic matter intake $(\mathrm{kg})$ & 13.77 & 12.77 & 12.65 & 12.77 & 13.58 & 9.4 & 0.3234 & 0.5221 & 0.6978 \\
\hline Non-fiber carbohydrates intake $(\mathrm{kg})$ & 3.90 & 3.80 & 3.75 & 3.73 & 3.82 & 3.8 & 0.3931 & 0.6129 & 0.5505 \\
\hline Crude protein intake $(\mathrm{kg})$ & 2.05 & 1.91 & 1.90 & 1.93 & 2.04 & 8.5 & 0.4980 & 0.6897 & 0.4392 \\
\hline Ether extract intake $(\mathrm{kg})$ & 0.49 & 0.49 & 0.48 & 0.50 & 0.53 & 8.7 & 0.5585 & 0.5891 & 0.5592 \\
\hline Total digestible nutrients intake $(\mathrm{kg})$ & 8.41 & 7.97 & 7.99 & 8.12 & 8.56 & 11.6 & 0.6727 & 0.7394 & 0.5986 \\
\hline
\end{tabular}

DM - dry matter; BW - body weight. 
control and the levels 100 and $150 \mathrm{~g} / \mathrm{kg}$, but the level $50 \mathrm{~g} / \mathrm{kg}$ decreased it compared with control. The authors state in their only comment about the NDFD that more studies should be conducted to elucidate the effect. There were no differences between treatments $(\mathrm{P}>0.05)$ for milk production (MP) and feed conversion (FC) (Table 7). Several studies in the literature found no significant differences for MP (Chung et al., 2007; Donkin et al., 2009; Wang et al., 2009; Rico et al., 2012; Shin et al., 2012). However, Boyd et al. (2009) evaluated the response of adding glycerol (none, 200 and $400 \mathrm{~g}$ ) in the diets of lactating cows and found a drop in milk production. On the other hand, Bodarski et al. (2005) evaluated the supply of 300 and $500 \mathrm{~mL}$ glycerol/day for lactating cows and found an increase of 14.6 and $12.5 \%$ in milk production compared with control. It appears that there are contrasting results between studies with glycerol, thus generating the possibility of interaction between glycerol and the other ingredients of the diet.

Milk production corrected for $35 \mathrm{~g} / \mathrm{kg}$ of fat (MPc), variation in body weight (BW) per period and per day and variation of body condition score (BCS) showed a decreasing linear effect $(\mathrm{P}<0.05)$ with increased levels of crude glycerin. In previous studies, Donkin et al. (2009) observed an increase in body weight with inclusion of glycerol at the levels of 100 and $150 \mathrm{~g} / \mathrm{kg}$, whereas for the level of $50 \mathrm{~g} / \mathrm{kg}$ it was similar to control. Wang et al. (2009), in turn, found elevation of body weight with increasing addition of glycerol.

An association between variation in BW (day and period) and in BCS regarding similarities of their effects was noticed in this trial. Each unit of BCS (0-5) represents a change of $82 \mathrm{~kg}$ BW for Holstein cows (NRC, 2001). The average variation of BCS in the BW found in this study was lower than the amount mentioned by the NRC (2001). For Girolando cows, with average initial body weight of $426.2 \pm 68.29 \mathrm{~kg}$, for each BCS unit, a variation of $24.7 \mathrm{~kg}$ in BW was observed.

Analyzing the results for variation in BW and TDMI, a plausible hypothesis is that efficiency for TDMI body weight gain reduces with increasing level of crude glycerin supplement. This effect may be due to several factors that affect the metabolism with decreased efficiency for milk synthesis. Donkin et al. (2009) suggest that changes in energy efficiency may be due to direct effects on rumen fermentation of glycerol metabolism. Studies with postpartum cows receiving glycerol in the diet (Chung et al., 2007) or water (Osborne et al., 2009) reported reductions

Table 6 - Apparent digestibility of lactating primiparous cows grazing on tropical levels of crude glycerin inclusion in the supplement, with its corresponding coefficient of variation $(\mathrm{CV}, \%)$

\begin{tabular}{|c|c|c|c|c|c|c|c|c|c|}
\hline \multirow{2}{*}{ Item $(\mathrm{g} / \mathrm{kg})$} & \multicolumn{5}{|c|}{ Levels of crude glycerin (g/kg supplement) } & \multirow{2}{*}{$\mathrm{CV}$} & \multicolumn{3}{|c|}{ P value } \\
\hline & 0 & 94 & 191 & 289 & 389 & & Linear & Quadratic & Lack of fit \\
\hline Dry matter digestibility & 591.5 & 591.2 & 594.9 & 605.4 & 600.5 & 5.0 & 0.3593 & 0.6782 & 0.1872 \\
\hline Organic matter digestibility & 646.7 & 644.4 & 651.1 & 658.4 & 651.0 & 4.0 & 0.4890 & 0.5743 & 0.6508 \\
\hline Neutral detergent fiber digestibility & 424.9 & 415.9 & 437.9 & 437.7 & 445.3 & 12.9 & 0.4271 & 0.6489 & 0.4287 \\
\hline Non-fiber carbohydrates digestibility & 902.5 & 883.2 & 875.3 & 880.4 & 864.6 & 5.6 & 0.5072 & 0.7228 & 0.7395 \\
\hline Crude protein digestibility & 635.3 & 642.4 & 645.1 & 660.9 & 648.7 & 6.8 & 0.2845 & 0.4739 & 0.8439 \\
\hline Ether extract digestibility ${ }^{1}$ & 505.8 & 609.3 & 642.2 & 629.1 & 639.5 & 16.7 & 0.0298 & 0.4329 & 0.6082 \\
\hline Total digestible nutrients & 590.4 & 597.6 & 607.1 & 606.1 & 600.3 & 5.1 & 0.3192 & 0.5391 & 0.5631 \\
\hline
\end{tabular}

${ }^{1}$ EED - ether extract digestibility: $\hat{Y}=547.71+6.383 \times$ CG $\left(r^{2}=0.63\right)$

$\mathrm{CG}$ - crude glycerin.

Table 7 - Productive parameters of primiparous lactating cows grazing on tropical pastures consuming different levels of crude glycerin inclusion in the supplement, with their respective coefficient of variation $(\mathrm{CV}, \%)$

\begin{tabular}{|c|c|c|c|c|c|c|c|c|c|}
\hline \multirow{2}{*}{ Item } & \multicolumn{5}{|c|}{ Levels of crude glycerin (g/kg supplement) } & \multirow{2}{*}{$\mathrm{CV}$} & \multicolumn{3}{|c|}{$P$ value } \\
\hline & 0 & 94 & 191 & 289 & 389 & & Linear & Quadratic & Lack of fit \\
\hline Daily milk production $(\mathrm{kg})$ & 13.3 & 14.3 & 14.3 & 14.0 & 13.6 & 16.7 & 0.3482 & 0.7589 & 0.6078 \\
\hline Daily milk production corrected for $35 \mathrm{~g}$ fat $/ \mathrm{kg}$ of milk $(\mathrm{kg})^{1}$ & 19.19 & 18.31 & 18.14 & 17.40 & 17.88 & 7.05 & 0.0243 & 0.0464 & 0.1495 \\
\hline Feed conversion ( $\mathrm{kg} \mathrm{DM} / \mathrm{kg}$ milk) & 0.75 & 0.73 & 0.73 & 0.77 & 0.80 & 12.13 & 0.5670 & 0.8609 & 0.7590 \\
\hline Body weight variation in period $(\mathrm{kg})^{2}$ & 8.0 & 11.4 & 1.1 & -2.7 & -11.0 & 724.9 & 0.0396 & 0.7865 & 0.6790 \\
\hline Body weight variation per day $(\mathrm{kg})^{3}$ & 0.53 & 0.76 & 0.07 & -0.18 & -0.73 & 724.9 & 0.0396 & 0.7865 & 0.6790 \\
\hline Body condition score variation (unit) ${ }^{4}$ & 0.05 & 0.05 & -0.12 & -0.05 & -0.20 & 439.5 & 0.0412 & 0.4978 & 0.3473 \\
\hline
\end{tabular}

${ }^{1} \hat{Y}=18.894-0.0786 \times C G+0.0043 \times C^{2}{ }^{2}\left(r^{2}=0.84\right)$.

${ }^{2} \hat{Y}=11.78-1.1578 \times C G\left(r^{2}=0.86\right)$.

${ }^{3} \hat{Y}=785.33-77.185 \times C G\left(r^{2}=0.86\right)$.

${ }^{4} \hat{Y}=0.065-0.0133 \times C G\left(r^{2}=0.75\right)$.

$\mathrm{CG}$ - crude glycerin. 
in plasma betahidroxibutirate levels. These results suggest a metabolic change to reduce the oxidation of fatty acids to ketones or increase the use of ketones by extrahepatic tissues when the animals are fed glycerol.

Despite the fact that ruminants use volatile fatty acids as their main energy source, glucose increases its role in lactating cows due to their high energy requirement, thus depending on glucose, which is mainly produced via hepatic gluconeogenesis (85\%). Glycerol can be used in the production of glucose by the liver, or be recombined with free fatty acids and non-esterified fatty acids for the synthesis of triglycerides. The liver uses the $\beta$-oxidation of fatty acids and long-chain acids for energy, and two acids of two carbons converted to acetyl-CoA combine with oxaloacetate for entry into the Krebs cycle. Some acid oxaloacetate can be used in gluconeogenesis, leading to limiting amounts of acetyl-CoA derived from $\beta$ oxidation, which can enter the Krebs cycle. The circulating concentrations of glycerol may serve to modulate the modification of adipose tissue triglycerides. These data point to unexplored possibilities of the interference of the post-ruminal glycerol metabolism in the dairy cow, modulating its lipid metabolism (Donkin et al., 2009).

Despite the fact that the reproductive parameters were not the main goal of the current study, it is noteworthy that the loss of weight and body condition can lead to increased inefficiency in reproduction, depending on the speed and extent of tissue loss involved.

The fat content and yield showed a quadratic effect between treatments $(\mathrm{P}<0.05)$ (Table 8). According to the equation found, the lowest values are found at 132 and $126 \mathrm{~g} / \mathrm{kg}$ for the milk fat content and yield, respectively. However, evaluating the addition of glycerol in diets for lactating cows, Ogborn (2006) and Wang et al. (2009) observed no differences in fat content between levels of crude glycerin. Donkin \& Doane (2007) found that milk composition was not affected by the addition of glycerol at $150 \mathrm{~g} / \mathrm{kg}$ of diet DM. Therefore, the lower milk fat content in the diet with the addition of glycerol is consistent with DeFrain et al. (2004) and Chung et al. (2007), who reported a lower production of milk fat when animals were fed glycerol.

According to Oliveira et al. (2007), the highest level of milk fat reduction is produced by the isomer of conjugated linoleic acid C18:2 trans10cis12, inhibiting enzymes promoting lipogenesis in the mammary gland. Most of this isomer is synthesized endogenously by enzyme delta-9desaturase present in the mammary gland, using fatty acids C18:1 trans-11 and C18:1 trans-7 assubstrates, formed during the process of ruminal biohydrogenation of polyunsaturated fatty acids in the diet (Griinari et al., 2000). Diets that are high in concentrates, low in forage, with finely chopped forage and added ionophores have resulted in higher levels of C18:2 trans-10cis-12 (Baumgard et al., 2000). However, this study is not characterized by the presence of factors that could induce this effect, such as high levels of concentrate, low forage, and finely chopped forage with addition of ionophores, thus promoting depression of fat in milk. For protein, lactose, total solids, dry nonfat, regarding fat: protein, milk urea nitrogen (MUN) and somatic cell count (SCC), no significant differences were observed $(\mathrm{P}>0.05)$ between the treatments.

Donkin et al. (2009), working with glycerol levels in the diets $(0,50,100$ and $150 \mathrm{~g} / \mathrm{kg})$ of Holstein cows, found differences in MUN, decreasing linearly with increased levels of glycerol. The decreasing effect of the

Table 8 - Milk composition of primiparous lactating cows grazing on tropical levels of crude glycerin inclusion in the supplement, with its corresponding coefficient of variation $(\mathrm{CV}, \%)$

\begin{tabular}{|c|c|c|c|c|c|c|c|c|c|}
\hline \multirow{2}{*}{ Item } & \multicolumn{5}{|c|}{ Levels of crude glycerin (g/kg supplement) } & \multirow{2}{*}{$\mathrm{CV}$} & \multicolumn{3}{|c|}{$P$ value } \\
\hline & 0 & 94 & 191 & 289 & 389 & & Linear & Quadratic & Lack of fit \\
\hline Fat $(\mathrm{g} / \mathrm{kg})^{1}$ & 46.8 & 42.3 & 42.1 & 38.6 & 41.4 & 12.3 & 0.0391 & 0.0272 & 0.0553 \\
\hline Fat $(\mathrm{kg})^{2}$ & 0.80 & 0.72 & 0.72 & 0.66 & 0.71 & 12.3 & 0.0391 & 0.0272 & 0.0553 \\
\hline Protein $(\mathrm{g} / \mathrm{kg})$ & 38.2 & 36.5 & 35.4 & 36.4 & 36.4 & 13.4 & 0.9069 & 0.6043 & 0.8920 \\
\hline Protein $(\mathrm{kg})$ & 0.65 & 0.62 & 0.60 & 0.62 & 0.62 & 13.4 & 0.9069 & 0.6043 & 0.8920 \\
\hline Lactose (g/kg) & 49.2 & 46.5 & 46.5 & 47.1 & 46.6 & 9.1 & 0.4029 & 0.5357 & 0.2805 \\
\hline Lactose $(\mathrm{kg})$ & 0.84 & 0.79 & 0.79 & 0.80 & 0.79 & 9.1 & 0.4029 & 0.5357 & 0.2805 \\
\hline Total solids (g/kg) & 144.5 & 135.1 & 133.3 & 131.5 & 133.5 & 8.3 & 0.1390 & 0.4623 & 0.1422 \\
\hline Total solids & 2.47 & 2.31 & 2.28 & 2.24 & 2.28 & 8.3 & 0.1390 & 0.4623 & 0.1422 \\
\hline Nonfat dry extract (g/kg) & 97.7 & 92.8 & 91.2 & 91.9 & 92.1 & 9.9 & 0.7516 & 0.8798 & 0.6610 \\
\hline Nonfat dry extract $(\mathrm{kg})$ & 1.67 & 1.58 & 1.56 & 1.57 & 1.57 & 9.9 & 0.7516 & 0.8798 & 0.6610 \\
\hline Fat:protein ratio & 1.24 & 1.16 & 1.23 & 1.07 & 1.14 & 19.4 & 0.6758 & 0.8574 & 0.5745 \\
\hline Milk urea nitrogen (mg/dL) & 15.34 & 14.40 & 16.83 & 16.05 & 15.75 & 15.4 & 0.3432 & 0.1862 & 0.3051 \\
\hline Somatic cell count $(\mathrm{x} 103 / \mathrm{mL})$ & 131 & 106 & 112 & 110 & 108 & 85.7 & 0.1973 & 0.0713 & 0.7078 \\
\hline
\end{tabular}

${ }^{1} \hat{Y}=46.729-1.03 \times C G+0.039 \times C^{2}\left(r^{2}=0.86\right)$.

${ }^{2} \hat{\mathrm{Y}}=0.7979-0.0176 \times \mathrm{CG}+0.0007 \times \mathrm{CG}^{2}\left(\mathrm{r}^{2}=0.86\right)$.

$\mathrm{CG}$ - crude glycerin. 
MUN, also found by DeFrain et al. (2004), is probably due to the effect of gliconeogenic glycerol that increases energy intake thereby reducing the excretion of nitrogen as urea in milk. However, other studies have found no effect of glycerol on MUN (Ogborn, 2006; Chung et al., 2007). Milk urea nitrogen was found at an average of $15.67 \mathrm{mg} / \mathrm{dL}$ for production of $13.9 \mathrm{~kg}$ milk/day, which is above the value found by Lucci et al. (2006) of $14.15 \mathrm{mg} / \mathrm{dL}$ for the treatment that completely met the requirements of crude protein, but the production was $12.4 \mathrm{~kg}$ milk/day. The MUN value calculated by the equation suggested by Meyer et al. (2006) is $11.0 \mathrm{mg} / \mathrm{dL}$ (MUN $=9.52+0.1054$ $\left.\times \mathrm{MP} ; \mathrm{r}^{2}=0.65\right)$, well below the actual value found in this study, thus rendering the equation in this system unreliable. The SCC was used to monitor the occurrence of subclinical mastitis in the cows studied, which could influence milk production and composition. Mean SCC was lower than 200000 cells $/ \mathrm{mL}$ in all treatments. According Aquino et al. (2007), these results are predictable, since milk production was maintained by the diets supplied, indicating adequate supply of nutrients to animals.

According to Chung et al. (2007), substances such as salts and methanol, which are co-producers of glycerol during the synthesis, can influence the palatability of the final product. Thompson et al. (2006) mention that when these substances are added in rations, the fat content should be noted. If methanol is a glycerol contaminant, its level should be controlled according to the federal and state regulations considering biodiesel glycerol to be acceptable as an animal feed.

It was found that the use of crude glycerin in the diet of lactating cows requires a prior adaptation period. Donkin et al. (2009) stated that seven days would be enough, but 10 days were used in this trial. Nevertheless, after the seventh day, all animals consumed the concentrates fed to them.

Considering the use of crude glycerin at $389 \mathrm{~g} / \mathrm{kg}$ in the supplement for cows and the actual increase in production in the biodiesel industry resulting in greater availability of glycerin, it becomes an attractive coproduct for feeding lactating cows. This is further emphasized due to the price of crude glycerin which is currently reduced along with a decreased availability of corn as feedstuff caused by the ethanol industry (Yazdania \& Gonzalez, 2007; Donkin et al., 2009).

\section{Conclusions}

For primiparous lactating cows grazing on tropical pasture, up to $389 \mathrm{~g}$ per $\mathrm{kg}$ of crude glycerin in supplement can be added without nutritional and productive interference.
In regions where the milk producer receives a rebate based on the fat content, a cost/benefit analysis of glycerin should be conducted, since glycerin promotes fat depression in milk. Care must be taken with the weight loss of the animals so as not to interfere with reproductive parameters.

\section{References}

ASSOCIATION OF OFFICIAL AGRICULTURAL CHEMISTS AOAC. Official methods of analysis. 17.ed. Gaithersburg: AOAC Int., 2000.

AQUINO, A.A.; BOTARO, B.G.; IKEDA, F.S. et al. Efeito de níveis crescentes de uréia na dieta de vacas em lactação sobre a produção e a composição físico-química do leite. Revista Brasileira de Zootecnia, v.36, n.4, p.881-887, 2007.

BAUMGARD, L.H.; CORL, B.A.; DWYER, D.A. et al. Identification of the conjugated linoleic acid isomer that inhibits fat synthesis. Animal Journal Physiology Regulatory Integrative, v.278, p.179-184, 2000.

BODARSKI, R.;WERTELECKI, T.; BOMMER, F. et al. The changes of metabolic status and lactation performance in dairy cows under feeding tmr with glycerin (glycerol) supplement at periparturient period. Electronic Journal Polish Agricultural Universities, v.8, n.4, p.22-30, 2005.

BOYD, J.; WEST, J.W.; BERNARD, J.K. Effects of increasing concentrations of dietary glycerol on ruminal environment and digestibility in lactating dairy cows. Journal of Dairy Science, v.92, n.1, p.88, 2009.

CAMPBELL, A.G. Grazed pastures parameters: I. Pasture dry matter production and availability in a stocking rate and grazing management experiment with dairy cows. Journal of Agriculture Science, v.67, p.211-216, 1966.

CASALI, A.O.; DETMANN, E.; VALADARES FILHO, S.C. et al. Influência do tempo de incubação e do tamanho de partículas sobre os teores de compostos indigestíveis em alimentos e fezes bovinas obtidos por procedimentos in situ. Revista Brasileira de Zootecnia, v.37, n.2, p.335-342, 2008.

CHUNG, Y.H.; RICO, D.E.; MARTINEZ, C.M. et al. Effects of feeding dry glycerin to early postpartum Holstein dairy cows on lactational performance and metabolic profiles. Journal of Dairy Science, v.90, p.5682-5691, 2007.

DEFRAIN, J.M.; HIPPEN A.R.; KALSCHEUR, K.F. et al. Feeding glycerol to transition dairy cows: Effects on blood metabolites and lactation performance. Journal of Dairy Science, v.87, p.4195-4206, 2004.

DETMANN, E.; VALADARES FILHO, S.C. On the estimation of nonfibrous carbohydrates in feeds and dietas. Arquivo Brasileiro de Medicina Veterinária e Zootecnia, v.62, n.4, p.980-984, 2010.

DONKIN, S.S.; DOANE, P. Glycerol as a feed ingredient in dairy rations. In: THREE-STATE DAIRY NUTRITION CONFERENCE, 2007, Fort Wayne. Proceedings... Fort Wayne: The Ohio State University, Michigan State University, Purdue University, 2007. p.97-103.

DONKIN, S.S.; KOSER, S.L.; WHITE, H.M. et al. Feeding value of glycerol as a replacement for corn grain in rations fed to lactating dairy cow. Journal of Dairy Science, v.92, n.10, p.5111-5119, 2009.

DONKIN, S.S.; PALLATIN, M.R.; DOANE, P.H. et al. Performance of dairy cows fed glycerol as a primary feed ingredient. Journal of Dairy Science, v.90 (Suppl. 1), p.350, 2007.

EDMONSON, A.J.; LEAN, I.J.; WEAVER, L.D. et al. A body condition scoring chart for Holstein dairy cows. Journal of Dairy Science, v.72, p.68-78, 1989.

EIFERT, E.C.; LANA, R.P.; LANNA, D.P.D. et al. Perfil de ácidos graxos do leite de vacas alimentadas com óleo de soja e monensina no início da lactação Revista Brasileira de Zootecnia, v.35, n.1, p.219-228, 2006. 
FISHER, L.J., ERFLE, J.D., SAUER, F.D. Preliminary evaluation of the addition of glucogenic materials to the rations of lactating cows. Canadian Journal Animal Science, v.51, p.721-727, 1971.

GARDNER, A.L. Técnicas de pesquisa em pastagem e aplicabilidade de resultados em sistema de produção. Brasília: IICA/EMBRAPA, CNPGL, 1986. 197p.

GRIINARI, J.M.; CORI, B.; LACY, S. et al. Conjugated linoleic acid is synthesized endogenously in lactating dairy cows by delta-9 desaturase. Journal of Nutrition, v.130, p.2285-2291, 2000.

JOHNSON, A.D. Sample preparation and chemical analysis of vegetation. In: t'MANNETJE, L. (Ed.). Measurement of grassland vegetation and animal production. Aberystwyth: Commonwealth Agricultural Bureaux, 1978. p.96-102.

KHALILI, H.; VARVIKKO, T.; TOIVONEN, V. et al. The effects of added glycerol or unprotected free fatty acids or a combination of the two on silage intake, milk production, rumen fermentation and diet digestibility in cows given grass silage based diets. Agricultural Food Science in Finland, v.6, p.349-362, 1997.

LUCCI, C.S.; VALVASORI, E.; PEIXOTO JUNIOR, K. et al. Concentrações de nitrogênio na dieta, no sangue e no leite de vacas lactantes no period pós-parto. Revista Brasileira de Zootecnia, v.35, n.1, p.258-263, 2006.

McMENIMAN, N.P. Methods of estimating intake of grazing animals. In: REUNIÃO ANUAL DA SOCIEDADE BRASILEIRA DE ZOOTECNIA, SIMPÓSIO SOBRE TÓPICOS ESPECIAIS EM ZOOTECNIA, 34., 1997, Juiz de Fora. Anais... Juiz de Fora: Sociedade Brasileira de Zootecnia, 1997. p.131-168.

MERTENS, D.R. Predicting intake and digestibility using mathematical models of ruminal function. Journal of Animal Science, v.64, p.1548-1558, 1987.

MEYER, P.M.; MACHADO, P.F.; COLDEBELLA, A. et al. Fatores não-nutricionais e concentração de nitrogênio uréico no leite de vacas da raça Holandesa. Revista Brasileira de Zootecnia, v.35, n.3, p.1114-1121, 2006 (supl.).

NATIONAL RESEARCH COUNCIL - NRC. Nutrient requirements of dairy cattle. 7.ed. Washington: National Research Council, 2001. 381p.

OGBORN, K.L. Effects of method of delivery of glycerol on performance and metabolism of dairy cows during the transition period. 2006. 154p. MS Thesis (Animal Science) Cornell University, Ithaca, NY.

OLIVEIRA, V.S.; FERREIRA, M.A.; GUIM, A. et al. Substituição total do milho e parcial do feno do capim-tifton por palma forrageira em dietas para vacas em lactação. Produção, composição do leite e custos com alimentação. Revista Brasileira de Zootecnia, v.36, n.4, p.928-935, 2007.

OSBORNE, V.R.; ODONGO, N.E.; CANT, J.P. et al. Effects of supplementing glycerol and soybean oil in drinking water on feed and water intake, energy balance, and production performance dairy cows. Journal of Dairy Science, v.92, n.2, p.698-707, 2009

PAULINO, M.F.; DETMANN, E.; VALADARES FILHO, S.C. Suplementação animal em pasto: energética ou protéica?. In: SIMPÓSIO SOBRE MANEJO ESTRATÉGICO DA PASTAGEM, 3., 2006, Viçosa, MG. Anais... Viçosa, MG: SIMFOR, 2006. p.359-392.

RICO, D.E.; CHUNG, Y.H.; MARTINEZ, C.M. et al. Effects of partially replacing dietary starch with dry glycerol in a lactating cow diet on ruminal fermentation during continuous culture. Journal of Dairy Science, v.95, n.6, p.3310-3317, 2012.

SHIN, J.H.; WANG, D.; KIM, S.C. et al. Effects of feeding crude glycerin on performance and ruminal kinetics of lactating Holstein cows fed corn silage- or cottonseed hull-based, low-fiber diets. Journal of Dairy Science, v.95, n.7, p.4006-4016, 2012.

THOMPSON, J.C.; HE, B.B. Characterization of crude glycerol from biodiesel production from multiple feedstock. Applied Engineering in Agriculture, v.22, n.2, p.261-265, 2006.

TYRRELL, H.F.; REID, J.J. Prediction of the energy value of cow's milk. Journal of Dairy Science, v.48, p.1215-1223, 1965.

WANG, C.; LIU, Q; YANG, W.Z. et al. Effects of glycerol on lactation performance, energy balance and metabolites in early lactation Holstein dairy cows. Animal Feed Science and Technology, v.151, p.12-20, 2009

WILM, H.G.; COSTELLO, D.F.; KLIPPLE, G.E. Estimating forage yield by the double sampling method. Journal of American Society of Agronomy, v.36, p.194-203, 1994.

YAZDANIA, S.S.; GONZALEZ, R. Anaerobic fermentation of glycerol: a path to economic viability for the biofuels industry. Current Opinion Biotechnology, v.18, p.213-219, 2007. 